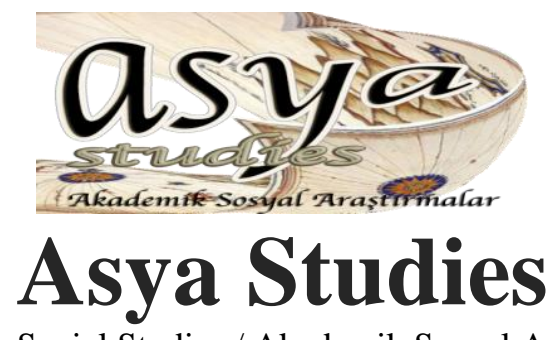

Academic Social Studies / Akademik Sosyal Araştırmalar Year: 5 - Number: 15, p. 181-183, Spring 2021

\title{
Ali Şir Nevâyî, Kitâb-ı Münşeat, Türk Kültürünü Araştırma Enstitüsü Yayınları, Ankara-2020, 316 s., ISBN 978-975-456-158-6
}

DOI: https://doi.org/10.31455/asya.866908

\section{Kitap Değerlendirme / Book Review}

Makale Geliş Tarihi / Article Arrival Date 23.01.2021

Makale Kabul Tarihi / Article Accepted Date 06.03.2021

Makale Yayın Tarihi / Article Publication Date 31.03.2021

\section{Asya Studies}

Arş. Gör. Çağla Barikan Topci İstanbul Kültür Üniversitesi, FenEdebiyat Fakültesi, Türk Dili ve Edebiyatı Bölümü

c.barikan@iku.edu.tr

\section{ORCID ID}

https://orcid.org/0000-0003-0034-5386

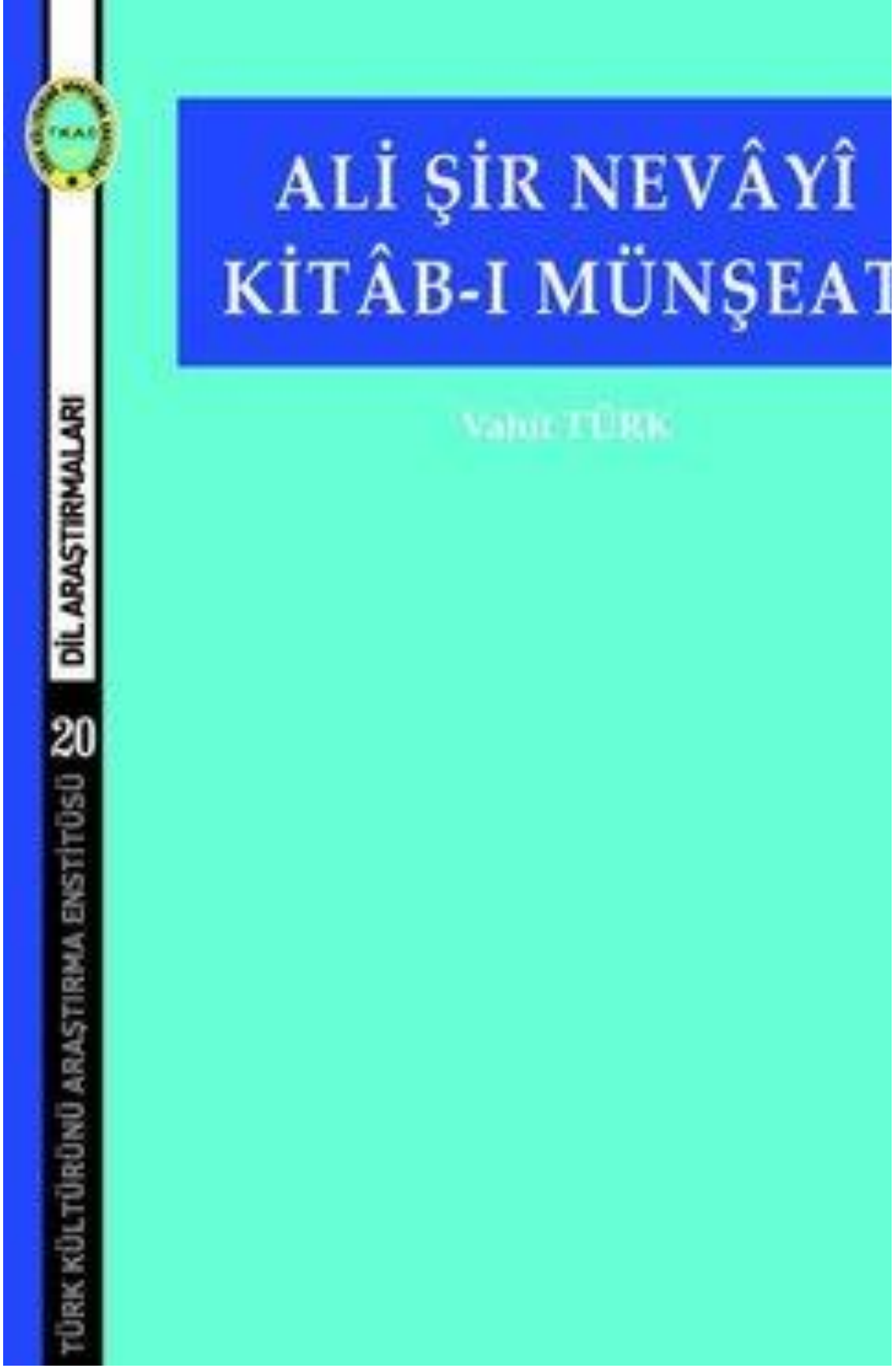

Barikan Topci, Ç. (2021). Ali Şir Nevâyî, Kitâb-1 Münşeat, Türk Kültürünü Araştırma Enstitüsü Yayınları, Ankara-2020, 316 s., ISBN 978-975-456-158-6. Asya Studies-Academic Social Studies / Akademik Sosyal Araştırmalar, Year:5, Number: 15, Spring, p. 181-183. 
Bir edebî tür olarak "düzyazı" anlamına gelen "inşa" sözcüğünden türemiş olan münşeat, "Mektup dahil her türlü resmî ve hususî yazıyı toplayan, yazım esaslarını gösteren eserlerin genel adı" olarak tanımlanmaktadır (Uzun, 2016: 18). Türk edebiyatındaki ilk münşeat örneklerinin XIV. yüzyılda görüldüğü bilinmektedir: "Türk edebiyatında ilk örnekleri XIV. yüzyılda görülmeye başlayan ve XX. yüzyıla kadar bir edebî gelenek halinde devam eden bu mecmuaların muhtevasını resmî ve özel yazışma ile mektuplar yanında manzum mektuplar, bunları süsleyen değişik manzumeler, nutuk, makale, arzuhal ve duânâmeleri de içine alan örnekler oluşturmaktadır. Böylece münşeat, özellikle Osmanlı kültüründe şiirleri toplayan divanlar gibi her çeşit nesri bir araya getiren bir telif türü halinde gelişmiştir" (Uzun, 2016: 18). Söz konusu edebî geleneğin Doğu Türkçesindeki ilk örneği Ali Şir Nevâyî tarafından kaleme alınmıştır.

Türk edebiyat ve kültür tarihinin öncü şairi ve mütefekkiri Ali Şir Nevâyî, Türkistan coğrafyasında kaleme aldığı eserlerle çağdaşlarına, kendisinden sonra yetişen kalemlere ve bütün Türk coğrafyasına Türkçenin gücünü, inceliklerini gösteren eserler miras bırakmıştır. Doğu Türkçesi ile kaleme aldığ 1 eserlerle Klasik Çağatay Türkçesinin en güzel örneklerini veren Nevâyî, Türk edebiyatının değişik konu ve alanlarında mihenk taşı olan ilk eserleri ortaya koymasıyla bilinir. Bu eşsiz eserleri ile Klasik Çağatay dönemi "Nevâyî Dili" olarak adlandırıldı. Nevâyî’nin Türkçeye hak ettiği değeri vererek ince ve akıcı bir üslupla ürettiği eserler yalnızca Doğu Türkçesini değil, Osmanlı şairlerini de derinden etkilemiş, onun eserlerine pek çok şair tarafindan nazireler yazılmıştır.

Ali Şir Nevâyî’nin kaleme aldığı Münşeat Kitabı, çeşitli zamanlarda farklı kişilere yazılan kimi mektupların ve inşa örneklerinin bir araya getirilmesiyle oluşturulmuş bir eserdir. Söz konusu mektupların hitap kısımları olmadığı için kime yazıldığı net olarak bilinmemekle birlikte bazılarının içeriklerinden çıkarım yapılabilmektedir (Abik, 1993: 21). Eser, Doğu Türkçesinin ilk münşeat kitabı olma özelliği, Nevâyî’nin akıcı ve samimi üslubu, dönemin sosyo-kültürel hayatına dair bazı bilgiler vermesi yönleri ile dikkat çekicidir. Kitâb-1 Münşeat, Türkiye'de 1965-1968 yılları arasında Âgâh Sırrı Levend'in dört ciltten oluşan "Ali Şir Nevâî" adlı çalışmasında ele alınmış, 1993 yılında Mustafa Canpolat danışmanlığında Ayşehan Deniz Abik tarafından doktora tezi olarak hazırlanmıştır. Türkiye'de Ali Şir Nevâyî ve onun eşsiz eserleri ile ilgili pek çok ilmi çalışmalar yapılmıştır, yapılmaya da devam etmektedir. Ancak kalemiyle Türk coğrafyasını birleştiren Nevâyî’yi daha iyi anlayabilmek onun eserlerini XV. yüzyıldan XXI. yüzyıla taşıyabilmek, kuşkusuz bu eşsiz eserleri günümüz Türkçesine aktarmaktan geçebilirdi. Prof. Dr. Vahit Türk, uzun yıllardır Nevâyî ile ilgili kaleme aldığı yapıtlarında, alanyazındaki bu açığı kapatarak onun dilini günümüz Türkçesine aktarmış, biz okurlara Nevâyî’yi çağdaş dilimizle okuma imkânı sunmuştur. Türk'ün bir dizi kitap olarak kaleme aldığı söz konusu eserler, okurun zihnine Nevâyî’nin söylem dünyasının kapılarını aralamıştır.

Prof. Dr. Vahit Türk tarafindan 2020 y1lında Türk Kültürünü Araştırma Enstitüsü Yayınları tarafından Nevâyî dizisinin sekizincisi olarak yayınlanmış olan bu değerli eser, çeviri yazılı metin, Türkiye Türkçesine aktarma, dizin, sözlük ve tıpkıbasım olmak üzere başlıca dört bölümden oluşmaktadır.

Kitabın birinci bölümünü oluşturan çeviri yazılı metin başlığı altında, eserin Süleymaniye Kütüphanesi'nin Fatih Bölümü 4056 numarada kayıtlı olan Külliyat nüshası esas alınmıştır. Metnin çeviri yazılı aktarmasında Bibliothèque nationale de France Katalog Général'de bulunan Külliyat nüshasında yer alan metin, Taşkent'te on cilt olarak yayımlanan Nevâyî eserlerinin 2011 baskısındaki metinlerle karşılaştırılmış, Paris nüshası $\mathrm{P}$, Taşkent nüshası T harfleri ile gösterilerek nüsha farklılıkları her sayfanın altında dipnotlar ile verilmiştir.

Kitabın ikinci bölümünü oluşturan Türkiye Türkçesine aktarma başlığı altında, eser Türkiye Türkçesine aktarılmıştır. Bu aktarma yapılırken metnin aslına sadık kalınmaya çalışılmış, şiir bölümleri düz yazı şeklinde yazıya geçirilmiş̧ir. Eserin başlangıcında Nevâyî bu eseri kaleme alma amacını şu şekilde açıklar: "Türklerin yazışmaları ve anlayışlı kimselerin açıklama ve tavırları ile bir kişi, bir kişiye hitaben bir şey yazdığında veya bir kişiye gelen yazıya cevap verdiğinde ya da yazıyı getiren ulağı geri döndürecek olduğunda, sözleri güzel olmaktan uzak, yazdıklarının düzeni özensiz, edaları hoş nüktelerden yoksun ve içeriği de güzel beyitlerle bezenmemiş olurdu. Buna karşıllk olarak Farsça yazılan inşalar gönlü okşayıcı ve imlâları da oldukça özenli idi. Türkçe ile yapılan yazışmaların da Farsçadakiler örnek alınarak yapılması ve bu dilin mektuplarının da Farsça mektuplar gibi olması gerektiğini düşündüm.” (Türk, 2020: 65) Nevâyî’nin -bu açıklaması doğrultusunda- Türkçe yazışmaların da Farsça örneklerde olduğu gibi özenli, güzel ve şairane olması isteği, onun bilinçli Türkçeciliğini ve Türkçenin de Farsçayla yarışabilecek düzeyde zengin bir dil olduğu gerçeğini gözler önüne sermektedir. 
Kitabın üçüncü bölümünü oluşturan Dizin başlığı altında, metinde geçen tüm sözcüklerin sözcük anlamlarının verildiği ve sözcüklerin geçtiği yerlerin gösterildiği bir dizin oluşturulmuştur. Dizin, Reşit Rahmeti Arat'ın Kutadgu Bilig dizininde gösterdiği düzene göre yapılmıştır. Eserin dördüncü bölümünü oluşturan Tıpkıbasım başlığı altına, on yedi varaktan oluşan Arap harfli metnin orijinal şekli eklenmiştir.

Bu değerli eseri XV. yüzyıl kitaplığından çıkararak XXI. yüzyılın diline aktaran ve Nevâyî’yi günümüz diliyle roman tadında okumamızı, anlamamızı sağlayan Prof. Dr. Vahit Türk'e teşekkür borçluyuz.

\section{KAYNAKÇA}

Abik, A. D. (1993). Ali Şir Nevayi'nin Risaleleri Tarih-i Enbiya ve Hükema, Tarih-i Müluk-i Acem, Münşeat: Metin- Gramatikal İndeks-Sözlük, (Yayımlanmamış Doktora Tezi), (Danışman: Prof.

Dr. Mustafa Canbolat), Ankara: Ankara Üniversitesi Sosyal Bilimler Enstitüsü.

Türk, V. (2020). Ali Şir Nevâyî Kitâb-ı Münşeat. Ankara: Türk Kültürünü Araştırma Enstitüsü Yayınları. Uzun, M. İ. (2006) . Münşeat. İstanbul: TDV İslâm Ansiklopedisi. 